\title{
Unemployment Risk, Precautionary Saving, and

\author{
Durable Goods Purchase Decisions
}

\author{
Wendy E. Dunn \\ Board of Governors of the Federal Reserve System \\ Wendy.E.Dunn@frb.gov
}

October 15, 1998

\begin{abstract}
In this paper household level data are used to explore whether unemployment risk is an important factor in the timing of durable goods purchase decisions. A theoretical model is presented in which both income uncertainty and household debt play a direct role in spending decisions. The model predicts that consumers respond to increases in unemployment risk by postponing purchases of the durable good and reducing their spending on nondurable goods in order to bolster their precautionary buffer-stock of liquid assets. It also implies that as consumers grow older and accumulate savings for retirement their consumption decisions become less sensitive to unemployment risk. Using unemployment probability estimates constructed from the Current Population Survey, a model of home purchase decisions for households in the 1983 and 1992 Surveys of Consumer Finances is estimated. Consistent with the theoretical model, there is evidence that unemployment risk has a direct effect on the timing of home purchases: households with a higher probability of becoming unemployed are less likely to have recently purchased a home, even after controlling for demographic variables. The prediction that older consumers are less sensitive to unemployment risk is also validated. Similar tests of car purchase decisions indicate that consumers who face greater unemployment risk are also less likely to purchase a vehicle. Finally, another finding consistent with the theoretical model is that consumers who are observed to have bought a house despite facing high unemployment risk tend to have more liquid assets left over than homebuyers who face ordinary or low unemployment risks.
\end{abstract}

JEL Classification: D91, E21

Keywords: precautionary saving, income uncertainty, durable goods

The views expressed are solely those of the author and do not necessarily represent those of the Board of Governors or the staff of the Federal Reserve System. I am grateful to Larry Ball, Carl Christ, Sarah Stafford, Mike Fratantoni, Chris Carroll, Karen Dynan, Spencer Krane and participants in the NBER Summer Institute for valuable comments. 


\section{Introduction}

Over the last decade a large body of literature has shown that uncertainty has important effects on household spending decisions. In particular, precautionary saving models such as those of Deaton (1991), Zeldes $(1989)$ and Carroll $(1992,1997)$ predict that consumers react to increases in income uncertainty by cutting consumption in order to increase their stock of precautionary savings. These models are important because they have been able to shed light on several well-known, empirical consumption puzzles that were previously unexplained by standard life-cycle and permanent-income models. ${ }^{1}$ For example, Caballero $(1990,1991)$ shows that assumptions of precautionary saving and positive correlation of labor income and its variance provide potential explanations for both the 'excess smoothness' and 'excess sensitivity' of consumption to unanticipated and anticipated changes in labor income, respectively. Carroll (1997) finds that the consumption-age profiles of several different education groups more closely match the income-age profiles implied by a precautionary saving model than those implied by a standard life-cycle model. Hubbard, Skinner, and Zeldes $(1994,1995)$ argue that the distribution of wealth held by the U.S. population is consistent with a precautionary saving model in which individuals face uncertainty about earnings, lifespan, and medical expenses.

From a macroeconomist's perspective, one major shortcoming of these models is that they only examine the implications of income uncertainty for nondurable goods consumption, ignoring uncertainty's affect on durable goods purchases. Yet durable goods are consistently the most cyclically volatile component of household spending. Moreover, several authors including Blanchard (1993) and Hall (1993) have blamed the most recent recession on a 'spontaneous decline in consumption'; Hall (1993), in particular, finds an important role for durable goods. Hence, an understanding of the factors that influence durable goods spending decisions is essential in explaining the impact of changes in consumption over the business cycle. By specifically addressing consumption of durable goods, this paper extends the relevance of existing work on precautionary saving. In addition, it provides an analysis of the microeconomic foundations of precautionary saving behavior, an important task in evaluating traditional representative-agent macroeconomic models of consumer behavior.

The paper also addresses a new topic in the research on durable goods, namely, the effects of labor

\footnotetext{
${ }^{1}$ For statements of the empirical consumption puzzles, see Deaton (1992), Campbell and Deaton (1989), and Flavin (1981).
} 
income uncertainty on the timing of individual households' durable goods purchases. Recent work by Caballero (1993), Bertola and Caballero (1990), Eberly (1994), Bar-Ilan and Blinder (1992) and others has argued that at the individual level, the optimal consumption path for durables can be described as following an $(\mathrm{S}, \mathrm{s})$ rule. When the stock of a durable good falls below some lower bound $s$, a purchase is made and the stock is readjusted to a target size $S$. As long as the stock of the durable good remains above the trigger point $s$, no action is taken. Grossman and Laroque (1990) and Eberly (1997) use models of this type to demonstrate the effects of rate of return uncertainty on households' durable goods consumption decisions. Carroll and Dunn (1997b) present an (S,s) model in which consumers face labor income uncertainty and show that unemployment expectations are a strong predictor of durable goods purchases at the aggregate level. None, however, have used household level data to explore whether unemployment risk is a significant factor in durable goods purchase decisions.

To begin the discussion, Section 2 presents a theoretical model of consumption of durable and nondurable goods in which both income uncertainty and household debt play a direct role in spending decisions. In the model, the purchase decision can be described as following a modified (S,s) rule, where the precise trigger point at which the consumer decides to make a purchase depends on both the anticipated risk of unemployment and the size of the consumer's current buffer stock of liquid assets. Increases in unemployment risk cause the $(\mathrm{S}, \mathrm{s})$ trigger point to shift downward, implying that a consumer with a given stock of the durable will require a larger stock of precautionary liquid assets before he or she will be willing to make a purchase. The model predicts that consumers respond to increases in unemployment risk by postponing purchases of the durable good and reducing their spending on nondurable goods in order to bolster their precautionary buffer-stock of liquid assets. Because consumers wait longer to purchase a house when unemployment risk is high, this also means that they will have more liquid assets left over after the purchase actually takes place. In addition, the model implies that as consumers grow older and accumulate savings for retirement, they become less sensitive to unemployment risk because their retirement savings can also serve as precautionary savings.

To test the predictions of the theoretical model, I examine the relationship between unemployment risk and durable goods purchases using household level data from the 1983 and 1992 Survey of Consumer Finances (SCF). Details on the method of estimation, data sources, and sample selection 
are provided in Sections 3 and 4. Ideally, panel data on individual households would be used to test the time series implications of the theoretical model; unfortunately, existing panel datasets do not contain the variables necessary to study both home and car purchases, or to construct the level of liquid assets held by each household. Cross sectional surveys like the SCF provide detailed consumption and balance sheet information, but only for a given point in time. But because the SCF data contain a representative sample of households from the nine U.S. Census regions, regional variation in economic conditions can be used to represent roughly the same differences in economic conditions observed over time in the aggregate economy. In other words, observation of the effects of differences in anticipated unemployment at a single point in time may provide valuable insight into the behavior of the overall economy as unemployment risk changes over time. In addition, interviews for the 1983 and 1992 surveys took place at roughly the same point in the business cycle, i.e. as the economy was recovering from a recession. This is fortunate because it means that differences between the two waves of the survey due to overall economic conditions should be relatively minor.

Several tests are conducted to evaluate the validity of the implications of the theoretical model. The first is an examination of whether unemployment risk is a significant consideration in the household's decision to make a major purchase of a durable good such as a home or a car. This is accomplished by estimating a probit model in which the dependent variable is an indicator of whether the household recently purchased a house, and among the independent variables is a proxy for unemployment risk. Specifically, the proxy for unemployment risk is an estimate of the probability that a currently employed consumer is unemployed the following year. This variable is constructed in two steps: first, data from the Current Population Survey (CPS) are used to estimate an individual's expected probability of unemployment based on demographic and other variables common to both the CPS and the SCF. The estimated coefficients are then used to calculate the probability of unemployment for households in the SCF. A variable for the interaction between age and unemployment risk is also added to the list of independent variables to test the prediction that individuals' sensitivity to unemployment risk varies with age. The last test is one in which the dependent variable is the individual household's level of liquid assets, and the sample includes only recent homebuyers.

The empirical results are presented in Section 5. Consistent with the theoretical model, the 1992 data indicate that anticipated unemployment risk has a direct effect on the timing of home purchases; 
however, there are notable differences between the two waves of the SCF. In 1983, unemployment risk does not appear to be a significant factor in the home purchase decision; but in 1992, households with a higher expected probability of unemployment are less likely to have recently purchased a home, even after controlling for demographic variables. The prediction that older consumers are less sensitive to unemployment risk is also validated by the results for 1992. Similar tests of car purchase decisions indicate that consumers who face greater unemployment risk are also less likely to purchase a vehicle, but again only for the 1992 sample. Finally, an examination of the balance sheets of consumers who have recently purchased a home shows that unemployment risk and liquid assets are positively correlated; again, this result is consistent with the behavior of consumers in the theoretical model.

It should be emphasized that the differences in the results for 1983 and 1992 with respect to unemployment risk may be related to the financial deregulation that took place between the two waves of the SCF. In the 1980s, credit market deregulation and financial market innovations led to large increases in household debt to income ratios, particularly mortgage debt. Liquidity constraints were loosened in several ways, including a lowering of the minimum required down payment ratio on home purchases. The theoretical model actually predicts that one effect of a reduction in the down payment ratio should be an increase in the response of consumers to fluctuations in uncertainty (see Carroll and Dunn (1997b)). This is a particularly surprising result because economic intuition suggests that increased credit availability should reduce consumption variability; instead, Carroll and Dunn (1997b) show that a loosening of liquidity constraints can have exactly the opposite effect. This is because when households make a smaller down payment they hold less equity in their homes, and hence less home equity to draw on in case of adverse income shocks. To compensate for this, households react more cautiously to changes in unemployment risk. Therefore, the empirical results are consistent with the idea that the credit market deregulation of the 1980s has resulted in an increased sensitivity of consumers to income uncertainty.

\section{A Model of the Durable Goods Purchase Decision}

In this section I present a summary of a theoretical model of the durable goods purchase problem for consumers who face the risk of becoming unemployed. In the model, consumers save for two reasons: to finance the down payment on a house and to accumulate precautionary savings as a buffer against 
bad times. The model is presented to help to formalize the relationship between unemployment risk and the durable goods purchase decision within the context of the household's overall optimization problem. Its implications are to be interpreted as a guide to the qualitative responses of consumers to changes in unemployment risk. Although presented as a model of the household's home purchase decision, it can also easily be interpreted as a model of the decision to purchase any major durable good that is debt-financed and requires saving for a down payment, such as a car. ${ }^{2}$

\subsection{The Utility Function}

The household's objective is to maximize the expected discounted value of lifetime utility from a nondurable good $(C)$ and the flow of services from a durable $(Z)$. The period utility function takes the standard form with constant relative risk aversion (CRRA) and Cobb-Douglas aggregation of goods and services:

$$
\max _{\left\{C_{t}, Z_{t}\right\}} \sum_{t=0}^{\infty} \beta^{t} E_{t}\left(\frac{\left(C_{t}^{1-\alpha} Z_{t}^{\alpha}\right)^{1-\rho}}{(1-\rho)}\right)
$$

The consumer's choice of $C_{t}$ and $Z_{t}$ in each quarter is constrained by the values of five state variables: (1) the level of 'cash on hand' $\left(X_{t}\right)$, which equals the sum of wealth and current labor income $\left(Y_{t}\right) ;(2)$ the stock of the durable owned by the consumer at the beginning of the quarter $\left(H_{t}^{b}\right)$; (3) the level of permanent labor income $\left(P_{t}\right) ;(4)$ the aggregate state of the economy $\left(I_{t}\right)$; and $(5)$ the consumer's current employment status $\left(J_{t}\right)$. The evolution of each of these is described below. $I_{t}, J_{t}$, and $P_{t}$ are all assumed to evolve exogenously, with permanent labor income following a first order Markov process with drift. It should be noted that the outstanding amount of mortgage debt is assumed to depreciate at the same rate as the value of the house. This simplification avoids the inclusion of mortgage debt as an additional state variable because it implies that ratio of mortgage debt to house value is always constant.

\subsection{The Homeownership Decision}

Consumers begin every quarter by making a decision regarding homeownership $\left(H_{t}^{e}\right)$ given the stock of owned housing with which they began the period $\left(H_{t}^{b}\right)$. Households who begin the period with

\footnotetext{
${ }^{2}$ The baseline model presented in this section is identical to that of Carroll and Dunn (1997b); in Section 2.9, however, I describe a finite-horizon model that is used to observe the responses of consumers of different ages to fluctuations in unemployment risk.
} 
no house $\left(H_{t}^{b}=0\right)$ have two choices: they can continue renting at cost $q \lambda$ where $q=1.5$ and $\lambda$ is the flow cost of homeownership, or they can buy a house whose value is equal to $\phi=3$ times their permanent income. ${ }^{3}$ At the time of purchase, buyers must put up a down payment of amount $d=.20$ proportional to the value of the house, and pay fees and taxes in amount $b=.03$. Households who begin the period owning a home have three choices: they can sell the house and rent, sell the house and buy another, or continue living in the same house. For homeowners, the flow of housing services is equal to the size of the house $\left(Z_{t}=H_{t}^{e}\right)$, and the cost of servicing debt in each period is equal to a fixed mortgage rate $m=\delta+r=.04$, where $\mathrm{r}$ is the after-tax real rate of interest and $\delta$ is the depreciation rate of the house. These choices are summarized in the following table, where $S_{t}$ denotes the level of liquid assets that the consumer holds at the end of the period:

\begin{tabular}{|l|c|c|c|c|}
\hline $\begin{array}{l}\text { Initial } \\
\text { Status }\end{array}$ & $\begin{array}{c}\text { Period } t \\
\text { Action(s) }\end{array}$ & $S_{t}$ & $H_{t}^{e}$ \\
\hline$H_{t}^{b}=0$ & Keep Renting & $X_{t}-C_{t}-q \lambda Z_{t}$ & 0 & Optimal \\
$H_{t}^{b}=0$ & Buy & $X_{t}-C_{t}-(d+b) H_{t}^{e}-[m(1-d)+n] H_{t}^{e}$ & $\phi P_{t}$ & $H_{t}^{e}$ \\
$H_{t}^{b}>0$ & Sell and Rent & $X_{t}-C_{t}+(d-b) H_{t}^{b}-q \lambda Z_{t}$ & 0 & Optimal \\
$H_{t}^{b}>0$ & Hold & $X_{t}-C_{t}-[m(1-d)+n] H_{t}^{e}$ & $H_{t}^{b}$ & $H_{t}^{e}$ \\
$H_{t}^{b}>0$ & Sell and Buy & $X_{t}-C_{t}+(d-b) H_{t}^{b}-(d+b) H_{t}^{e}$ & $\phi P_{t}$ & $H_{t}^{e}$ \\
\hline
\end{tabular}

\subsection{The Aggregate State of the Economy}

The aggregate economy is assumed to be in one of three states, expansion, contraction, or recovery. ${ }^{4}$ The consumer has no control over the aggregate state $\left(I_{t}\right)$. Expansions are characterized by high income growth and low unemployment, contractions by high unemployment and low income growth, and recoveries by high income growth and high unemployment. Contractions, which are expected to last for four quarters, are always followed by a period of recovery, which is also expected to last four quarters. This reflects the fact that postwar recessions in the U.S. have usually been followed by periods of higher than average unemployment. The Markov transition matrix for the aggregate state of the economy is therefore defined as follows:

\footnotetext{
${ }^{3}$ Notice that $q>1$, giving consumers an incentive to buy a house. The flow cost of home ownership $\lambda=r+n+\delta$, the sum of lost interest on the capital tied up in the house, maintenance, and depreciation costs, respectively. In the baseline model $r=.02, n=.05$, and $\delta=.02$ annually, making $\lambda=.09$

${ }^{4}$ See Sichel $(1993,1994)$.
} 


\begin{tabular}{l|cccc} 
& \multicolumn{3}{|c}{ Period $t+1$ Aggregate State } \\
\hline \multirow{3}{*}{ Period $t$} & Expansion & 0.95 & Contraction & Recovery \\
Aggregate & Contraction & 0.05 & 0.05 & 0 \\
State & Recovery & 0.25 & 0.70 & 0.25 \\
& & & 0.05 & 0.70
\end{tabular}

\subsection{Unemployment Shocks}

Transitions between employment states are governed by a Markov transition matrix that differs in contractions vs. expansions (recoveries are the same as contractions). In expansions the transition matrix is as follows:

\begin{tabular}{c|cccc} 
& \multicolumn{4}{|c}{ Period $t+1$ Status } \\
\hline Period & & $E$ & $U_{1}$ & $U_{2}$ \\
$t$ & $E$ & 0.97 & 0.01 & 0.02 \\
Status & $U_{1}$ & 0.97 & 0.01 & 0.02 \\
& $U_{2}$ & 0 & 1 & 0
\end{tabular}

while in contractions and recoveries the following transition matrix applies:

\begin{tabular}{c|cccc} 
& \multicolumn{4}{|c}{ Period $t+1$ Status } \\
\hline Period & & $E$ & $U_{1}$ & $U_{2}$ \\
$t$ & $E$ & 0.96 & 0 & 0.04 \\
Status & $U_{1}$ & 0.96 & 0 & 0.04 \\
& $U_{2}$ & 0 & 1 & 0
\end{tabular}

In each quarter employed consumers $(E)$ face a positive probability of becoming unemployed for one period (denoted $U_{1}$ ) or for two periods (denoted $U_{2}$ ). If they do become unemployed, consumers are assumed to know how long the given unemployment spell will last (one or two periods). Notice, however, that a consumer in the last period of an unemployment spell $\left(U_{1}\right)$ faces the same employment hazards as an employed consumer, so that consumers can in fact be unemployed for several periods. The probabilities are defined so that the average spell of unemployment is longer in contractions than in expansions. ${ }^{5}$

\subsection{Labor Income Shocks}

Labor income $\left(Y_{t}\right)$ is assumed to be subject to two types of shocks, permanent and transitory. The level of labor income in each period is defined as the level of permanent labor income $\left(P_{t}\right)$ multiplied by a transitory shock to income $\left(\Psi_{t}\right)$ :

\footnotetext{
${ }^{5}$ Probabilities were chosen to generate overall steady-state unemployment rates of roughly 5 percent in expansions and 8 percent in contractions and recoveries. See Carroll and Dunn (1997b) for further discussion of calibration of the model.
} 


$$
Y_{t}=P_{t} \Psi_{t}
$$

where $P_{t}$ follows a first-order Markov process with drift $G_{t+1}$ and stochastic shock $\Pi_{t+1}$ :

$$
P_{t+1}=G_{t+1} P_{t} \Pi_{t+1}
$$

The drift parameter is the mean growth rate of permanent income for employed consumers in period $t+1$. Its value, as well as the values of both labor income shocks, depends on the aggregate state of the economy. Permanent and transitory income shocks are drawn from a symmetric distribution with equal probability of each of three values. These values are summarized in the following table:

\begin{tabular}{cc|cc} 
& & Expansions & Contractions/Recoveries \\
\hline Drift & $G_{t+1}$ & $(1.05)$ & $(1.03)$ \\
Transitory Shocks & $\Pi_{t+1}$ & $(0.9,1.0,1.1)$ & $(0.9,1.0,1.1)$ \\
Permanent Shocks & $\Psi_{t+1}$ & $(0.95,1.00,1.05)$ & $(0.95,1.00,1.05)$
\end{tabular}

\subsection{The Optimization Problem}

Based on the above assumptions, the consumer's three control variables potentially are $C, H^{e}$, and $Z$, and the Bellman equation for the consumer's optimization problem can be written as follows:

$$
\begin{aligned}
& V_{t}\left(X_{t}, H_{t}^{b}, I_{t}, J_{t}, P_{t}\right)= \\
& \max _{\left\{C_{t}, Z_{t}, H_{t}^{e}\right\}} u\left(C_{t}, Z_{t}\right)+\beta E_{t} V_{t+1}\left(X_{t+1}, H_{t+1}^{b}, I_{t+1}, J_{t+1}, P_{t+1}\right)
\end{aligned}
$$

Given the process for permanent labor income and the assumption that the utility function is homogeneous of degree zero (plus certain other conditions that are satisfied by the constraints), the problem can be rewritten by expressing $C, Z, X$, and $H^{b}$ in terms of their ratio to permanent labor income (e.g. $\left.c_{t}=C_{t} / P_{t}\right)$. This effectively reduces the number of state variables from five $\left(X_{t}, H_{t}^{b}, I_{t}\right.$, $\left.J_{t}, P_{t}\right)$ to four $\left(x_{t}, h_{t}^{b}, I_{t}, J_{t}\right)$ :

$$
\begin{aligned}
& v_{t}\left(x_{t}, h_{t}^{b}, I_{t}, J_{t}\right)= \\
& \max _{\left\{c_{t}, z_{t}, h_{t}^{e}\right\}} u\left(c_{t}, z_{t}\right)+\beta E_{t}\left(G_{t+1} \Pi_{t+1}\right)^{1-\rho} v_{t+1}\left(x_{t+1}, h_{t+1}^{b}, I_{t+1}, J_{t+1}\right)
\end{aligned}
$$


where

$$
\begin{aligned}
h_{t+1}^{b} & =\frac{h_{t}^{e}(1-\delta)}{G_{t+1} \Pi_{t+1}} \\
x_{t+1} & =\frac{R}{G_{t+1} \Pi_{t+1}} s_{t}+\Psi_{t+1}
\end{aligned}
$$

\subsection{Solution}

Because an analytical solution is impossible, the model is solved using numerical stochastic programming techniques (see Carroll and Dunn (1997a)). The model takes approximately four days to solve and two days to simulate using a Sun workstation. In spite of these difficulties, the resulting consumption rules are relatively straightforward. Consumers primarily behave as standard "buffer stock" savers, maintaining a target stock of assets (or cash on hand) to use as a buffer against unexpected unemployment spells (see Deaton (1991) and Carroll $(1992,1997)$ ); however, when they are near the point at which they are ready to buy a new home, they do some extra saving to finance the required down payment. Because of the cost advantages, the large majority of consumers are homeowners most of the time.

The homeownership decision can be described as following an $(\mathrm{S}, \mathrm{s})$ rule with trigger points based on the ratio of home value to permanent income. Over time, the value of the house depreciates and permanent income grows; hence, this ratio drifts downward over time until it reaches a trigger point and the consumer purchases a new home. The value of the trigger point depends on both the anticipated risk of unemployment and the level of 'cash on hand'. Figure 1 shows the lower $(\mathrm{S}, \mathrm{s})$ band as a function of the level of cash on hand for a given period. The figure illustrates that increases in unemployment risk associated with contractions result in the trigger point "jumping" downward.

This "jump" in the lower (S,s) band implies that, for any given level of liquid assets, the trigger point at which a consumer will purchase a house is higher in expansions than recessions. This is because when the anticipated risk of unemployment increases, the target buffer stock of savings increases, and consumers who were previously about to purchase a home now find that they want to hold additional precautionary savings to offset the increased risk of a spell of unemployment. Therefore, they postpone the purchase of a home until they can accumulate enough liquid assets to again feel comfortable with the level of savings they will be left with after the home purchase (or until the ratio of home value to permanent income decreases to the new lower trigger point). This is a central result of the model, 


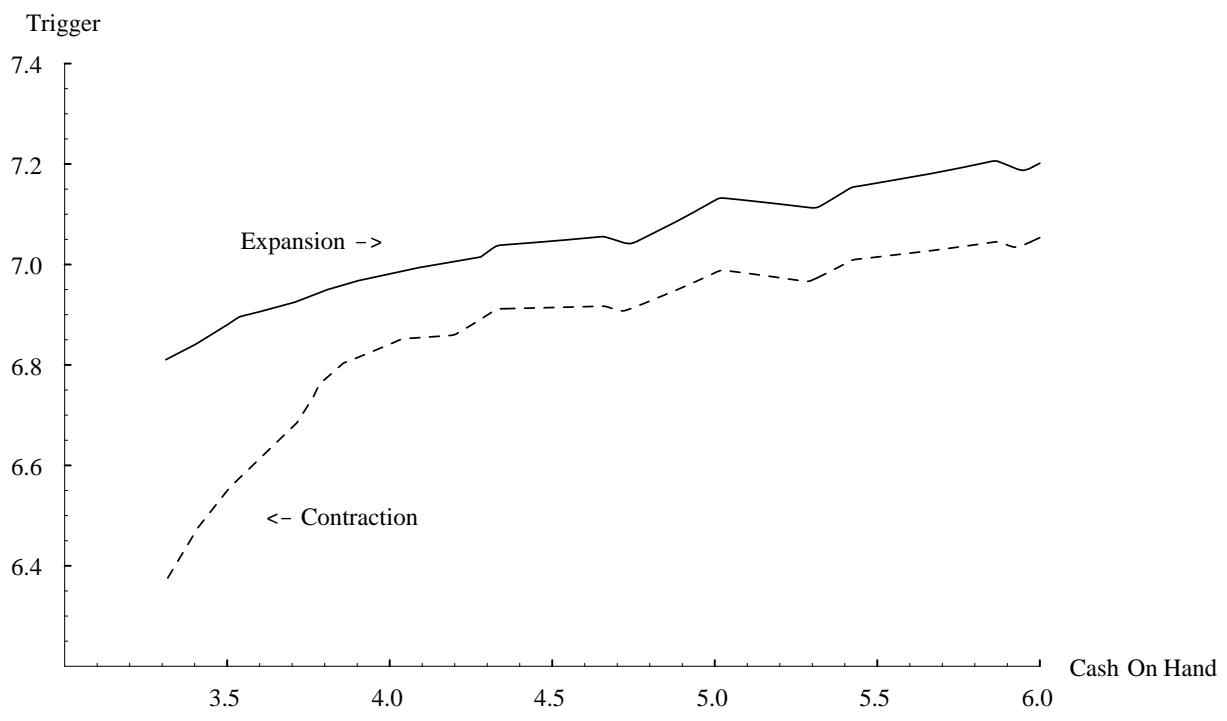

Figure 1: A Comparison of (S,s) Triggers in Expansions vs. Contractions

and is important because it provides a framework for explaining the behavior of home sales and other durable goods purchases over the business cycle.

\subsection{The Effects of Unemployment Risk in the Simulated Economy}

The relationship between unemployment risk and durable goods purchases in the theoretical model can also be understood by observing the movements in these variables over a simulated business cycle. This is accomplished by first simulating the economy for several quarters of expansion (in order to achieve a stochastic steady-state) and then hitting it with a recession. ${ }^{6}$ Figure 2 illustrates the movements in several important aggregates in the economy from several quarters before the recession to after the recovery period. The following variables are depicted: the unemployment rate; job loss risk; labor income; liquid assets; consumption of nondurables; and home purchases. Job loss risk is defined as the expectation of becoming unemployed over the next four quarters for an employed consumer. Aggregate labor income, liquid assets, and consumption of nondurables are actual sums over all households in the simulation. Home purchases are the fraction of the population that purchased a home in the given quarter. The values on the $\mathrm{x}$ axis indicate the number of quarters before and/or after the start of the recession. The four quarters of the recession are shaded dark gray and the four quarters of the recovery are shaded light gray.

\footnotetext{
${ }^{6}$ The economy is simulated with a population of 20,000 consumers. The initial expansion lasts for 400 quarters, ensuring that the consumers are reasonably distributed across the state space before a recession takes place.
} 

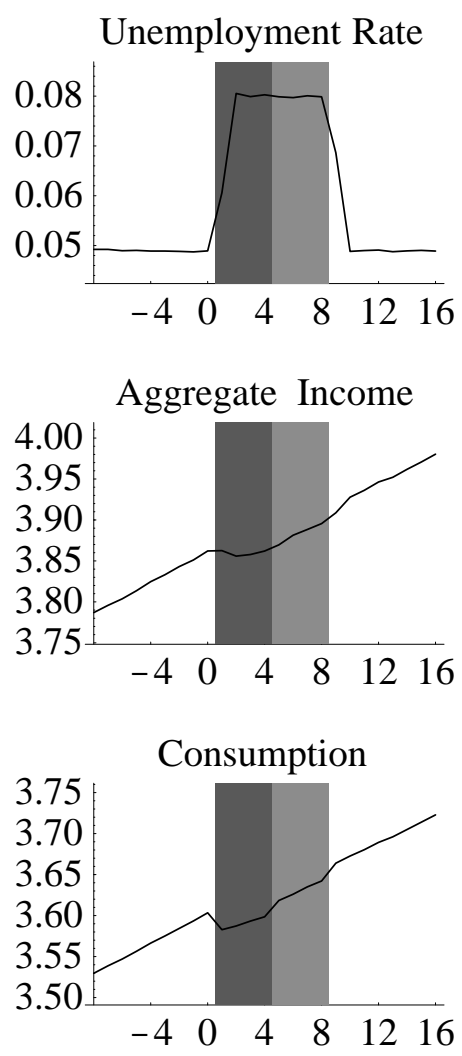

Job Loss Risk

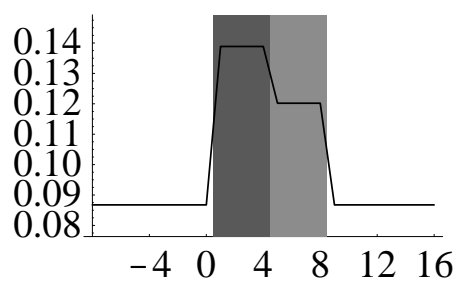

Liquid Assets

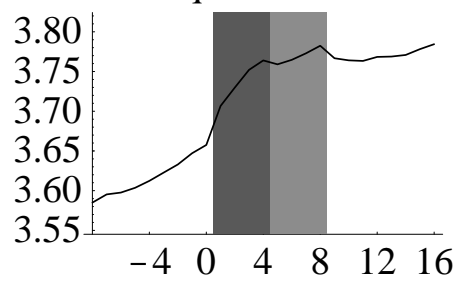

Home Purchases

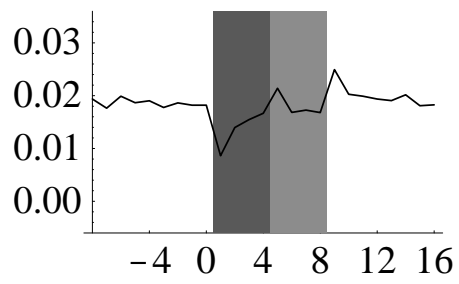

Figure 2: A Typical Recession in the Simulated Economy

At the onset of the recession, unemployment expectations immediately jump to the higher recessionary steady-state value. The actual unemployment rate follows closely behind as the higher risk of job loss actually begins to take affect and more consumers lose their jobs. The unemployment rate stays at the same high level throughout the recession and recovery periods, dropping back to its original level only in the second quarter after the end of the recovery. Aggregate income falls as the unemployment rate increases, and its growth remains sluggish until the unemployment rate returns to normal levels.

Both home purchases and consumption of nondurables drop sharply in the first quarter of the recession in response to the increase in expected job loss risk. This reflects the shift in the lower $(\mathrm{S}, \mathrm{s})$ band shown in Figure 1. When unemployment fears increase, consumers who were about to buy a house instead wait longer so they can accumulate more savings to offset the higher risk of 
unemployment. They also increase their precautionary saving by cutting spending on nondurables. This is illustrated in the figure for liquid assets; throughout the four quarters of the recession, aggregate liquid assets in the economy increase dramatically as consumers respond to the increase in expected job loss risk.

Figure 2 illustrates that as the economy moves through the recession and into the recovery period, consumption and income slowly return to their normal pre-recession levels. Liquid assets flatten out somewhat, and there is a small surge in home purchases. When the economy recovers fully and moves back into expansion, there is a large upward spike in home purchases and a small surge in nondurables consumption as consumers' expected job loss risk drops and a large quantity of 'pent-up demand' for the durable good is released.

These responses to changes in uncertainty over the business cycle reveal several implications of the theoretical model that can be tested empirically. First, as discussed above, increases in anticipated unemployment risk cause consumers to postpone their durable goods purchases. In a recession, consumers who were previously about to buy a house are unwilling to make a home purchase because they fear a spell of unemployment will draw down their assets too much. When the recession ends and unemployment fears ease, home purchases temporarily surge as consumers respond to the decreased need for precautionary savings. Put more formally, the model implies that the home purchase decision, i.e., the probability that a consumer will purchase a home in a given period, depends in part on his or her anticipated risk of unemployment.

Another interesting characteristic of the model is that consumers who are observed to have bought a house despite facing high unemployment risk will tend to have more liquid assets left over than homebuyers who face ordinary or low unemployment risks. The additional liquid assets are needed to offset the higher risk of job loss. In other words, the theoretical model implies a positive relationship between unemployment risk and the stock of liquid assets held by consumers who have just purchased a house.

\subsection{Differences in Responses Over the Life-cycle}

To observe how the responses of consumers to changes in income uncertainty differ over the life-cycle, the original model must be converted to one in which consumers are finite-lived. This is important 
because, in contrast to the previous model, optimal consumption rules will vary over the life-cycle of the consumer. This allows for a comparison of the reactions of consumers who experience a recession early in the life-cycle to the reactions of consumers who go through a recession later in the life-cycle. Therefore, in this section I briefly discuss the implications of an alternative model in which consumers are assumed to begin their economic lives at age 25 , retire after 40 years at age 65 , and live to a maximum age of 100 .

In addition to consumers being finite-lived, there are several other differences between this model and the previous one. First, the assumption that the growth rate of permanent income is constant is also relaxed; instead consumers face different growth rates over time, with high income growth when young (age 25 to 50), lower growth as they near retirement (age 50 to 65 ), and zero growth after retirement. Hence, the growth rate $G_{t}$ of permanent income for a consumer in each period depends on not only the aggregate state of the economy but also the age of the consumer. A growth rate that varies over the life-cycle provides a closer match to the actual patterns of lifetime income growth observed in household level data (see Carroll (1997)). This also means that consumers have another reason to save; in addition to precautionary saving and saving to finance a down payment, they must save for retirement, when income is low. ${ }^{7}$

Second, in each period the consumer faces a positive risk of mortality. Defining $D_{t}$ as a state variable that equals one if the individual is alive and zero otherwise, the period utility function takes the following form:

$$
\max _{\left\{C_{t}, Z_{t}\right\}} \sum_{t=0}^{T} \beta^{t} E_{t}\left(\frac{D_{t}\left(C_{t}^{1-\alpha} Z_{t}^{\alpha}\right)^{1-\rho}}{(1-\rho)}\right)
$$

This mortality risk calibration is taken from Hubbard, Skinner, and Zeldes (1995), who report the conditional probability at each age of surviving one more year based on mortality data from the National Center for Health Statistics and the Social Security Administration (see Faber (1982)).

As before, the model is solved using numerical methods, and a history is simulated for a large number of consumers. ${ }^{8}$ Overall, both the optimal consumption rules and simulation results for this

\footnotetext{
${ }^{7} \mathrm{At}$ retirement, there is also a one-time drop in income to 70 percent of permanent income.

${ }^{8}$ In the simulations, consumers begin their lives with zero assets and no house. Notice that because every consumer in the simulations is the same age, the results should be interpreted as describing the behavior of only a single age cohort, rather than an entire economy.
} 

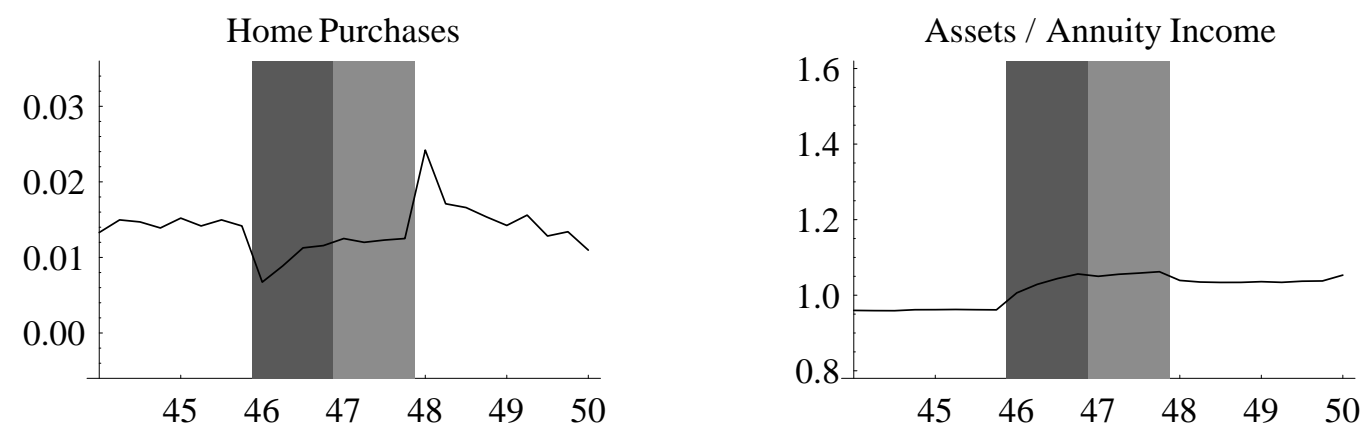

Figure 3: The Response of Home Purchases at Age Forty-Five

new model are similar to those in the previous section, with one notable difference: older consumers are generally less sensitive to unemployment risk than younger consumers. This is because in the theoretical model as consumers grow older, they build up a stock of liquid assets (cash on hand) in preparation for retirement, when income is low. This stock of assets serves a dual purpose in that it not only serves as savings for retirement but also provides the consumer with a protective stock of precautionary savings in case of an unexpected spell of unemployment. This means that older consumers automatically have more precautionary savings than the young and therefore tend to be less sensitive to unemployment risk.

This idea can best be understood by observing the reactions of consumers of different ages over the business cycle. Figures 3 and 4 show the results for two different simulations, one in which a recession takes place at age 45 (quarter 81), and another in which the recession takes place later in the life-cycle at age 55 (quarter 121). Each figure depicts movements in home purchases on the left-hand side. The adjoining figure shows the aggregate ratio of liquid assets to annuity income throughout the business cycle. ${ }^{9}$ The values on the $\mathrm{x}$ axis indicate the age of consumers in the simulations when the recession takes place. A comparison of the two sets of figures illustrates that younger consumers respond more strongly to the decrease in unemployment risk at the end of the recession. The figure for liquid assets relative to annuity income shows the reason for this: fifty-five year olds have more assets that serve a dual purpose as precautionary and retirement savings, so they respond less to unemployment risk over the business cycle.

In summary, if this characteristic of the model correctly describes the behavior of consumers as they

${ }^{9}$ Annuity income is defined as the annuity value of the present discounted value of future labor income. 

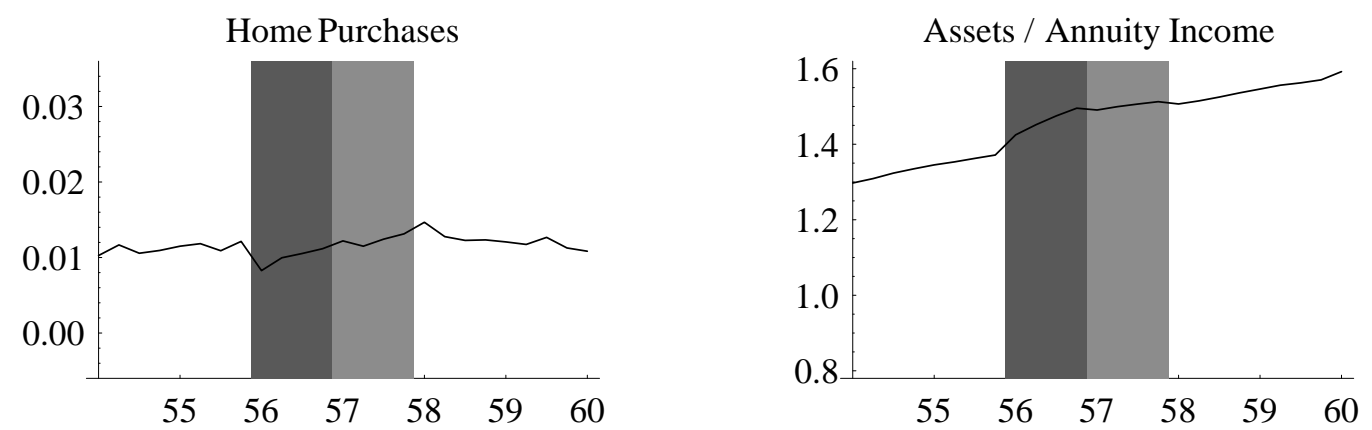

Figure 4: The Response of Home Purchases at Age Fifty-Five

age, then the timing of consumers' durable goods purchases should be less sensitive to anticipated unemployment risk later in the life-cycle. Stated formally, the results of the finite-horizon model imply that the probability that a consumer will purchase a durable good will be more sensitive to unemployment risk early in life, and less sensitive later in life.

\section{Data Sources and Sample Selection}

To test the predictions of the theoretical model, individual household data from the 1983 and 1992 waves of the Survey of Consumer Finances (SCF) are used. The SCF is useful because it provides detailed information on household income and balance sheets as well as a small amount of data on home purchases and other durable goods expenditures; however, the data are cross-sectional, providing only a snapshot of households for a given point in time. The most desirable method for testing the time series properties of the theoretical model would be to use a panel study, but existing panel datasets unfortunately do not contain all of the necessary variables.

Instead, an alternative method implemented here is to use regional differences in economic conditions at a single point in time to represent roughly the same differences in economic conditions observed over time in the aggregate economy. In other words, variation in unemployment across different regions can be used to capture differences in the probability of unemployment for individual households at a single point in time. The SCF contains a representative sample of households from the nine U.S. Census regions (except for the high income sub-sample of the SCF). It is also fortunate that interviews for the 1983 and 1992 waves of the SCF took place at roughly the same point in the business cycle because differences between the two waves of the survey due to overall economic 
conditions should be relatively small.

Another problem related to the data is that the SCF samples are too small to construct reliable estimates of the probability of becoming unemployed. This obstacle can be overcome by implementing a procedure originally devised by Carroll, Dynan and Krane (1997). Those authors use data from the Current Population Survey (CPS) to estimate an individual's expected probability of unemployment based on demographic and other variables common to both the CPS and the SCF. ${ }^{10}$ They then use the estimated coefficients from the CPS to calculate the probability of unemployment for households in the SCF. The CPS coefficients from Carroll, Dynan and Krane (1997) are used for the same purpose in this paper.

Finally, several restrictions are imposed on the sample included in the regressions. First, households with the highest and lowest .1 percent of income are dropped to avoid undue influence of extreme outliers on the regression. Households whose head is younger than 25 or older than age 65 are excluded because unemployment risk is not likely to be important for those who have not yet permanently entered the workforce or who have left it. Because region identifiers are not included for households in the high income sub-sample of the $1983 \mathrm{SCF}$, these households are necessarily omitted. Observations where any of the independent variables are missing are also dropped.

\section{Empirical Procedure}

In the first set of regressions I examine whether there is a significant relationship between unemployment risk and the individual household's decision to purchase a home. A probit model is estimated in which the dependent variable is an indicator of whether the household recently purchased a house, and among the independent variables is a proxy for unemployment risk. A recent home purchase is defined as one that took place within the last two years. The second set of regressions considers car purchases rather than home purchases. The last test involves a linear regression of the level of liquid assets held by households who have recently purchased a home. In each set of regressions, a two stage procedure is implemented in which estimates of unemployment risk and permanent income for each household are constructed in the first stage, and their effects on durable goods purchase decisions

\footnotetext{
${ }^{10} \mathrm{~A}$ different CPS sample is used to estimate unemployment risk for each wave of the SCF. The CPS samples used included respondents whose fourth interview fell in the twelve months preceding August 1983 and November 1992. These were chosen to match the interview dates for the 1983 and 1992 SCFs, which took place between February and August 1983 and June and November 1992, respectively.
} 
(or liquid assets) is measured in the second stage. All dollar amounts are deflated to 1992 constant dollars.

As discussed above, the first stage estimates of unemployment risk are based on the methodology of Carroll, Dynan and Krane (1997). A proxy for unemployment risk is constructed by estimating the probability that an employed individual in the CPS will become unemployed in the next year. This is done by running a logit regression in which the dependent variable is an indicator that equals one if the individual is employed in month $t$ and unemployed in month $t+12$, and zero if the individual is employed in both periods. The probability of unemployment for individual households in the SCF is then calculated using the estimated coefficients from the CPS. The variables in the unemployment probability regression include the following variables (available in both the CPS and the SCF): age; age squared; nine regional dummy variables; seven industry dummy variables; four education dummy variables; six occupation dummy variables; occupation interacted with age; education interacted with age; a marital status dummy variable; a dummy variable for whether the household head is white; a dummy variable for whether the household head is female; a dummy variable for the head of household; the head of household dummy variable interacted with age; and the head of household dummy interacted with gender. ${ }^{11}$

The first stage estimates of permanent income are based on a regression of the log of income (in 1992 dollars) on demographic and other variables available in the SCF. Separate regressions are run for each survey year. The instruments include all of those used to estimate unemployment probability, plus the following variables: the number of children under age 18 in the household; the number of income earning members of the household; a dummy variable for whether the household reported that it has been turned down for credit; a dummy variable for whether the household reported that it has had problems servicing loans; the log of retirement income; and a dummy variable for whether the household head has a defined benefit pension. ${ }^{12}$

To control for differences in the income process and other factors which might affect the house-

\footnotetext{
${ }^{11}$ The nine regional dummy variables are defined as follows: (1) New England; (2) Mid-Atlantic; (3) South Atlantic; (4) East South Central; (5) West South Central; (6) East North Central; (7) West North Central; (8) Mountain; (9) Pacific. The four education dummy variables are defined as follows: (1) no high school degree; (2) high school degree, but no college; (3) high school degree and some college; (4) college degree or more. The three digit 1980 Census occupation code is collapsed into six overall occupation groups, and the three digit 1980 Census industry code is collapsed into seven overall industry groups.

${ }^{12}$ The extra variables in the permanent income regressions are not in the unemployment probability regressions because these variables are available only in the SCF (not in the CPS).
} 
CPS First Stage Estimation Results for Unemployment Probability

\begin{tabular}{|l|c|c|}
\hline & 1983 & 1992 \\
\hline Occupation & 0.007 & 0.008 \\
\hline Industry & 0.000 & 0.000 \\
\hline Region & 0.012 & 0.000 \\
\hline Education & 0.000 & 0.001 \\
\hline White & 0.003 & 0.007 \\
\hline Female Head & 0.051 & 0.011 \\
\hline Age & 0.168 & 0.980 \\
\hline Age * Occupation & 0.011 & 0.097 \\
\hline Age * Education & 0.069 & 0.061 \\
\hline Mean Pr$(\hat{u})$ & 0.027 & 0.022 \\
\hline Std. Dev. Pr $(\hat{u})$ & 0.021 & 0.017 \\
\hline Number of Observations & 59,252 & 63,351 \\
\hline
\end{tabular}

Notes: Dependent variable equals one if unemployed at time $t+1$; zero otherwise. The sample includes all individuals who were employed at time $t$, including the self-employed. All values are $\mathrm{P}$-values for a test that the given coefficient (or set of coefficients for the dummy variables) equals zero. The following variables were also included as independent variables but are not reported: a constant term; a marital status dummy variable; a dummy variable for the head of household; the head of household dummy variable interacted with age; and the head of household dummy interacted with gender.

Table 1: Unemployment Probability Estimation

hold's purchase decision, permanent income and several basic demographic variables are included as independent variables in all of the second stage equations. Several controls were tested, including the following: age; education dummy variables; occupation dummy variables; industry dummy variables; the marital status dummy variable; the number of children; the number of income earners in the household; a dummy variable for whether the household head is female; a dummy variable for whether the household head is white; and a variety of interaction terms. Because the number of "successes" in the sample is small, i.e. few households actually bought houses within the last two years, only those few controls which appear to be robustly significant are included in the final equations.

\section{$5 \quad$ Results}

\subsection{First Stage Regressions for Unemployment Risk}

Table 1 summarizes the results of the unemployment probability estimation from the CPS data. The values listed are P-values from a test of the significance of the coefficient (or set of coefficients for the dummy variables). All of the controls except age are significant with at least 90 percent confidence, and most are significant with greater than 99 percent confidence. The standard deviations for both estimates also indicate that there is considerable variation in the predicted unemployment probabilities (between 70 and 80 percent of the means). 
SCF First Stage Estimation Results for Permanent Income

\begin{tabular}{|l|c|c|c|c|}
\hline \multirow{2}{*}{} & \multicolumn{2}{|c|}{ Full Sample } & \multicolumn{2}{c|}{ Excluding Self-Employed Households } \\
\cline { 2 - 5 } & 1983 & 1992 & 1983 & 1992 \\
\hline Occupation & 0.879 & 0.254 & 0.227 & 0.494 \\
\hline Occupation * Age & 0.087 & 0.004 & 0.001 & 0.016 \\
\hline Industry & 0.016 & 0.150 & 0.001 & 0.005 \\
\hline Region & 0.000 & 0.014 & 0.000 & 0.000 \\
\hline Education & 0.669 & 0.107 & 0.315 & 0.007 \\
\hline Education * Age & 0.719 & 0.687 & 0.655 & 0.110 \\
\hline Age & 0.000 & 0.000 & 0.000 & 0.000 \\
\hline White & 0.187 & 0.007 & 0.045 & 0.142 \\
\hline Female Head & 0.000 & 0.000 & 0.000 & 0.000 \\
\hline No. Children & 0.436 & 0.156 & 0.008 & 0.482 \\
\hline No. Income Earners & 0.000 & 0.440 & 0.000 & 0.014 \\
\hline Marital Status & 0.000 & 0.000 & 0.000 & 0.001 \\
\hline Pension Plan & 0.000 & 0.243 & 0.000 & 0.498 \\
\hline Turned Down for Credit & 0.158 & 0.001 & 0.333 & 0.096 \\
\hline Payment Problems & 0.162 & 0.059 & 0.341 & 0.106 \\
\hline R Square & 0.38 & 0.27 & 0.48 & 0.42 \\
\hline Number of Observations & 1618 & $8546 / 5$ & 1375 & $5528 / 5$ \\
\hline
\end{tabular}

Notes: The dependent variable is the log of income (in 1992 dollars). All values are P-values for a test that the given coefficient (or set of coefficients for the dummy variables) equals zero. A constant term was also included as an independent variable but is not
reported.

Table 2: Permanent Income Estimation

\subsection{First Stage Regressions for Permanent Income}

The results for the first stage estimation of permanent income are contained in Table 2. Results are shown for both the full sample and the sub-sample of households whose head is not self-employed. Again, all values listed are P-values from test of the significance of the given coefficient or set of coefficients. The adjusted $\bar{R}^{2}$ 's range between 25 and 45 percent for the regressions on the full sample and 40 and 50 percent for the sample that excludes self-employed households. Most of the basic demographic variables are statistically significant, with the exception of the occupation and education dummy variables; however, both sets of variables are jointly statistically significant in a regression with only those variables included. This suggests that these are important control variables in the regression, but there is some collinearity between them and the other independent variables (in particular occupation and education interacted with age). 


\subsection{Second Stage Regressions}

\subsubsection{The Home Purchase Decision}

The results of the second stage estimation of a probit model of the home purchase decision for the 1983 SCF can be found in Table 3 and for the 1992 SCF in Table 4. The left panel of each table lists results for the full sample, while the right panel lists results when self-employed households are excluded from the sample. ${ }^{13}$

Although the results for the 1983 wave of the SCF do not indicate a statistically significant relationship, all of the coefficients on unemployment risk have the expected negative sign. The only demographic variables that are robustly significant in the 1983 wave of the SCF are age, the number of children in the household, and the female head of household dummy variable; the coefficients on all of these are negative, implying that older households, households with children, and households whose head is female are less likely to have recently purchased a home. This makes some sense because, given the fact that both older households and households with children are in general more likely to already be homeowners, it is reasonable to expect that younger families (with no children) should make up a larger proportion of those buying houses. Permanent income is always negatively related to the home purchase probability and in most cases is significant with at least 95 percent confidence. Recall, however, that the dependent variable is an indicator for whether the household purchased a home within the last two years. Thus the negative coefficient suggests that high income households are less likely to have recently purchased a home, not that high income households are less likely to purchase a home at all.

Things look somewhat different, however, for the 1992 wave of the SCF. The basic equation including only permanent income and unemployment risk indicates that the probability that a household will purchase a home is negatively related to its anticipated probability of unemployment. The coefficient on unemployment risk is -14.3 for the full sample and -15.1 when self-employed households are excluded; both coefficients are statistically significant with greater than 99 percent confidence. Permanent income again has a negative sign and is also weakly statistically significant for the full sample. The test of overidentifying restrictions, however, rejects the baseline equation in favor of one

\footnotetext{
${ }^{13}$ The sub-sample excluding self-employed households is included because not only do self- employed households have arguably different attitudes toward risk, they have different, and much more ambiguous, definitions of what it means to be unemployed.
} 
The Home Purchase Decision 1983 Survey of Consumer Finances

\begin{tabular}{|l|c|c|c|c|c|c|}
\hline & \multicolumn{3}{|c|}{ Full Sample } & \multicolumn{3}{c|}{ Excluding Self-Employed Households } \\
\cline { 2 - 7 } & 1 & 2 & 3 & 4 & 5 & 6 \\
\hline $\log \hat{Y}^{p}$ & -0.068 & -0.701 & -0.679 & -0.067 & -0.665 & -0.598 \\
& $(-0.601)$ & $\left(-2.264^{* *}\right)$ & $\left(-2.186^{* *}\right)$ & $(-0.533)$ & $\left(-2.026^{* *}\right)$ & $\left(-1.786^{*}\right)$ \\
\hline $\operatorname{Pr}(\hat{u})$ & -3.305 & -2.126 & -10.577 & -2.274 & -7.771 & -17.946 \\
& $(-1.075)$ & $(-0.321)$ & $(-0.921)$ & $(-0.749)$ & $(-1.097)$ & $(-1.462)$ \\
\hline No. Children & & -0.104 & -0.105 & & -0.122 & -0.118 \\
& & $\left(-2.232^{* *}\right)$ & $\left(-2.249^{* *}\right)$ & & $\left(-2.375^{* * *}\right)$ & $\left(-2.298^{* *}\right)$ \\
\hline No. Earners & & 0.128 & 0.125 & & 0.135 & 0.127 \\
& & $(0.994)$ & $(0.966)$ & & $(0.942)$ & $(0.884)$ \\
\hline Marital Status & & 0.302 & 0.307 & & 0.176 & 0.155 \\
& & $(1.397)$ & $(1.418)$ & & $(0.776)$ & $(0.680)$ \\
\hline Age & & -0.027 & -0.033 & & -0.031 & -0.039 \\
& & $\left(-4.235^{* * *}\right)$ & $\left(-3.583^{* * *}\right)$ & & $\left(-4.548^{* * *}\right)$ & $\left(-3.622^{* * *}\right)$ \\
\hline Female Head & & -0.416 & -0.404 & & -0.455 & -0.434 \\
& & $\left(-1.828^{*}\right)$ & $\left(-1.776^{*}\right)$ & & $\left(-1.855^{*}\right)$ & $\left(-1.763^{*}\right)$ \\
\hline Age ${ }^{*}$ Pr $(\hat{u})$ & & & 0.245 & & & 0.278 \\
& & & $(0.918)$ & & & $(1.039)$ \\
\hline OID Test & $98.71^{* * *}$ & 27.91 & 27.09 & $90.55^{* * *}$ & 20.24 & 19.19 \\
\hline No. Observations & 1618 & 1618 & 1618 & 1375 & 1375 & 1375 \\
& & & & & & \\
\hline
\end{tabular}

* Significant at $10 \%$ or better. ** Significant at $5 \%$ or better. *** Significant at $1 \%$ or better.

Notes: The dependent variable equals one if a home was purchased within the last two years; zero otherwise. $\operatorname{Pr}(\hat{u})$ is the probability of unemployment and $\hat{Y}^{p}$ is permanent income. $t$ statistics are listed in parentheses below coefficient estimates. The following variables were included as independent variables but are not reported: education dummy variables; occupation dummy variables; industry dummy variables; and a constant term. The test of overidentifying restrictions is a standard likelihood ratio (LR) test.

Table 3: Estimation of the Home Purchase Decision

that includes one or more of the controls as independent variables. ${ }^{14}$

The second column of each panel in the table illustrates the results when several controls are added to the right-hand side of the equation, including the age of the household head, a dummy variable for whether the household head is female, a marital status dummy variable, the number of children under age 18 in the household, the number of income earning members of the household, and the dummy variables for education, occupation, and industry. In every case, the probability of unemployment remains negative and highly statistically significant, with coefficients ranging in size from roughly -20 to -55. Age is usually significant and negatively related to the probability of a recent home purchase; there is also some evidence that female household heads have a lower probability of a recent home

\footnotetext{
${ }^{14}$ The test of overidentifying restrictions is a standard likelihood ratio (LR) test; it was constructed by calculating the difference in the log likelihood of the given specification and one that includes all of control variables in the first stage that were excluded from the second stage equation.
} 
The Home Purchase Decision

1992 Survey of Consumer Finances

\begin{tabular}{|l|c|c|c|c|c|c|}
\hline & \multicolumn{3}{|c|}{ Full Sample } & \multicolumn{3}{c|}{ Excluding Self-Employed Households } \\
\cline { 2 - 7 } & 1 & 2 & 3 & 4 & 5 & 6 \\
\hline $\log \hat{Y}^{p}$ & -0.110 & -0.334 & -0.327 & -0.055 & -0.396 & -0.324 \\
& $\left(-1.774^{*}\right)$ & $\left(-1.852^{*}\right)$ & $\left(-1.801^{*}\right)$ & $(-0.658)$ & $(-1.396)$ & $(-1.127)$ \\
\hline $\operatorname{Pr}(\hat{u})$ & -14.337 & -22.336 & -54.900 & -15.116 & -19.553 & -54.852 \\
& $\left(-3.619^{* * *}\right)$ & $\left(-3.568^{* * *}\right)$ & $\left(-3.199^{* * *}\right)$ & $\left(-3.284^{* * *}\right)$ & $\left(-2.388^{* *}\right)$ & $\left(-2.550^{* *}\right)$ \\
\hline No. Children & & -0.008 & -0.008 & & 0.027 & 0.027 \\
& & $(-0.200)$ & $(-0.214)$ & & $(0.534)$ & $(0.547)$ \\
\hline No. Earners & & 0.009 & 0.004 & & 0.062 & 0.059 \\
& & $(0.095)$ & $(0.046)$ & & $(0.473)$ & $(0.448)$ \\
\hline Marital Status & & -0.113 & -0.099 & & -0.078 & -0.095 \\
& & $(-0.650)$ & $(-0.571)$ & & $(-0.361)$ & $(-0.438)$ \\
\hline Age & & -0.020 & -0.035 & & -0.014 & -0.033 \\
& & $\left(-3.322^{* * *}\right)$ & $\left(-3.701^{* * *}\right)$ & & $\left(-1.833^{*}\right)$ & $\left(-2.524^{* *}\right)$ \\
\hline Female Head & & -0.486 & -0.487 & & -0.388 & -0.368 \\
& $\left(-2.686^{* * *}\right)$ & $\left(-2.691^{* * *}\right)$ & & $\left(-1.792^{*}\right)$ & $\left(-1.694^{*}\right)$ \\
\hline Age ${ }^{*}$ Pr $(\hat{u})$ & & & 0.810 & & & 0.885 \\
& & & $\left(2.092^{* *}\right)$ & & & $\left(1.826^{*}\right)$ \\
\hline OID Test & $92.05^{* * *}$ & 16.67 & 12.30 & $62.33^{* * *}$ & 16.62 & 13.35 \\
& & & & & & \\
\hline No. Observations & $9338 / 5$ & $9338 / 5$ & $9338 / 5$ & $5748 / 5$ & $5748 / 5$ & $5748 / 5$ \\
& & & & & & \\
\hline
\end{tabular}

* Significant at $10 \%$ or better. ** Significant at $5 \%$ or better. *** Significant at $1 \%$ or better.

Notes: The dependent variable equals one if a car was purchased within the last two years; zero otherwise. $\operatorname{Pr}(\hat{u})$ is the probability of unemployment and $\hat{Y}^{p}$ is permanent income. t statistics are listed in parentheses below coefficient estimates. The following industry dummy variables; and a cont variables but are not reported: education dummy variables; occupation dummy variables;

Table 4: Estimation of the Home Purchase Decision

purchase. $^{15}$

One explanation for the differences between the results for the 1983 and 1992 waves of the SCF derives from the financial liberalization that took place in the mid- to late-1980s. Prior to the 1990 recession, financial deregulation and innovations in the financial markets led to large increases in the use of mortgage and consumer debt and overall household debt to income ratios. In addition, the minimum required down payment ratios on home mortgages generally decreased over this period. Carroll and Dunn (1997b) argue that one of the effects of this deregulation has been an increase in the response of consumers to fluctuations in income uncertainty. This is a very surprising result because standard economic intuition suggests that a relaxation of liquidity constraints should allow consumers to smooth consumption more than they could previously; instead, the authors show that a loosening

\footnotetext{
${ }^{15}$ Other age variables such as age squared and age category dummy variables were also tested; although in some cases the coefficients were significant, the inclusion of these variables did not affect the sign or significance of the unemployment risk variable.
} 
of liquidity constraints can actually have the opposite effect.

This happens in the theoretical model for two reasons. First, the lower down payment ratio implies that households hold less equity in their homes, so they have less home equity to draw on in case of unanticipated spells of unemployment or negative permanent income shocks. Buying a house therefore increases a household's exposure to uncertainty more than it did previously. The household compensates for this by reacting more cautiously to changes in unemployment risk. Second, financing the home purchase with a larger proportion of debt also means that the mortgage payment is larger. Because the quarterly payment is fixed and unavoidable (unless of course the household sells the house, incurring a loss in brokerage fees), once they have purchased a house households can only adjust consumption of nondurables in response to income shocks (see Fratantoni (1996)). As a result, households who make lower down payments are more hesitant to purchase a home because of the implied commitment to a series of larger required mortgage payments. Hence, it is not at all surprising that the effects of unemployment risk appear to be larger in size and more significant than the results for the $1983 \mathrm{SCF}$.

In the third column of each panel, the significance of the interaction between unemployment risk and age is tested by adding the product of these two variables to the list of independent variables. This interaction term should capture whether the sensitivity of home purchase decisions to unemployment risk changes as the household ages. As discussed above, the model implies that as households grow older and accumulate a stock of liquid assets in preparation for retirement, they become less sensitive to swings in unemployment risk because the stock of assets can also serve as a precautionary buffer against bad times. This suggests that the coefficient on the interaction term should be positive, so that the overall coefficient on unemployment risk is smaller for the old than for the young. Not only is this true for both years of data, the coefficients in the 1992 sample are significant with at least 90 percent confidence. This is an important point because it implies that the severity of recessions will depend in part on the demographic makeup of the population when unemployment risk increases.

Overall, there is strong evidence that the household's anticipated unemployment risk has a direct effect on the timing of home purchases. The regressions of the home purchase decision demonstrate that, after controlling for several basic demographic variables, households with a higher probability of an unemployment spell are less likely to have recently purchased a home. 


\subsubsection{Another Durable: The Car Purchase Decision}

Although the durable good in the model has thus far been interpreted as a house, the implications should also hold for other major debt-financed durables purchased by the household. In particular, in this section I test whether there is any evidence that unemployment risk also affects the household's decision to purchase a vehicle. The empirical specification is the same as before except that here the dependent variable is replaced with an indicator of whether the household recently purchased a vehicle.

The results for the car purchase regressions are listed in Tables 5 and 6 . Once again, the 1983 regressions do not seem to indicate that unemployment risk has a significant effect on car purchases. The coefficients are positive in the baseline regressions but negative when the control variables are included in the regression; however, the negative coefficients are only significant at roughly the 80 percent confidence level, suggesting that unemployment risk is not directly significant. ${ }^{16}$ The coefficient on permanent income is positive and significant with better than 99 percent confidence.

In the 1992 wave of the SCF, the coefficient on unemployment risk in the baseline model is negative and significant with at least 95 percent confidence in both the full sample and the sample excluding self-employed households (the coefficients are -11.9 and -8.8, respectively). As with housing, however, the baseline model is rejected by the test of overidentifying restrictions. After adding controls to the regression, the unemployment risk coefficient in the full sample remains significant with 95 percent confidence. When the age-unemployment risk interaction term is added (in the third panel), the unemployment risk coefficients are significant with 95 percent confidence, and the interaction term coefficients are significant with at least 90 percent confidence, indicating that the variation in the sensitivity to unemployment risk over the life-cycle that was seen in the housing regressions also extends to car purchases. In the 1992 data, the number of children and the number of income earning members of the household are also significant explanatory variables.

In both waves of the survey, permanent income is strongly related to the probability of a car purchase in the baseline equations; however, the coefficients are positive in 1983 and negative in 1992. In 1992, when additional controls are added to the list of regressors, the coefficients on permanent

\footnotetext{
${ }^{16}$ In the car regressions, the following controls are included as independent variables in the second and third columns of each panel: age of the household head, a dummy variable for whether the household head is female, a marital status dummy variable, the number of children under age 18 in the household, the number of income earning members of the household, and dummy variables for education, occupation, region, and the interaction between education and age.
} 
The Car Purchase Decision

1983 Survey of Consumer Finances

\begin{tabular}{|l|c|c|c|c|c|c|}
\hline & \multicolumn{3}{|c|}{ Full Sample } & \multicolumn{2}{c|}{ Excluding Self-Employed Households } \\
\cline { 2 - 7 } & 1 & 2 & 3 & 4 & 5 & 6 \\
\hline $\log \hat{Y}^{p}$ & 0.362 & 0.632 & 0.602 & 0.514 & 0.768 & 0.763 \\
& $\left(4.595^{* * *}\right)$ & $\left(2.766^{* * *}\right)$ & $\left(2.609^{* * *}\right)$ & $\left(5.849^{* * *}\right)$ & $\left(3.205^{* * *}\right)$ & $\left(3.189^{* * *}\right)$ \\
\hline $\operatorname{Pr}(\hat{u})$ & 2.578 & -3.706 & -12.317 & 4.559 & -1.402 & -12.403 \\
& $(1.278)$ & $(-1.235)$ & $(-1.275)$ & $\left(2.242^{* *}\right)$ & $(-0.498)$ & $(-1.285)$ \\
\hline No. Children & & 0.038 & 0.035 & & 0.068 & 0.066 \\
& & $(1.245)$ & $(1.134)$ & & $\left(2.018^{* *}\right)$ & $\left(1.942^{* *}\right)$ \\
\hline No. Earners & & 0.037 & 0.040 & & 0.056 & 0.055 \\
& & $(0.427)$ & $(0.459)$ & & $(0.578)$ & $(0.576)$ \\
\hline Marital Status & & 0.034 & 0.043 & & -0.050 & -0.052 \\
& & $(0.243)$ & $(0.306)$ & & $(-0.334)$ & $(-0.349)$ \\
\hline Age & & -0.005 & -0.007 & & 0.001 & -0.003 \\
& & $(-0.773)$ & $(-1.011)$ & & $(0.104)$ & $(-0.323)$ \\
\hline Female Head & & -0.091 & -0.103 & & -0.073 & -0.080 \\
& & $(-0.563)$ & $(-0.630)$ & & $(-0.417)$ & $(-0.457)$ \\
\hline Age ${ }^{*}$ Pr $(\hat{u})$ & & & 0.208 & & & 0.268 \\
& & & $(0.940)$ & & & $(1.195)$ \\
\hline OID Test & $112.73^{* * *}$ & 21.98 & 21.09 & $88.28^{* * *}$ & 12.59 & 11.16 \\
\hline No. Observations & 1618 & 1618 & 1618 & 1375 & 1375 & 1375 \\
& & & & & & \\
\hline
\end{tabular}

* Significant at $10 \%$ or better. ** Significant at $5 \%$ or better. *** Significant at $1 \%$ or better.

Notes: The dependent variable equals one if a car was purchased within the last year; zero otherwise. $\operatorname{Pr}(\hat{u})$ is the probability of unemployment and $\hat{Y}^{p}$ is permanent income. $t$ statistics are listed in parentheses below coefficient estimates. The following region dummy variables; as independent variables but are not reported: education dummy variables; occupation dummy variables; a standard likelihood ratio (LR) test.

Table 5: Estimation of the Car Purchase Decision

income are no longer significant. One possible explanation for this change in the sign of the coefficient on permanent income is that wealthy consumers shifted from owning cars to leasing them between 1983 and 1992. Unfortunately, in the 1983 survey there were no separate questions addressing cars leased by households. But in the 1992 survey, several questions addressed cars that were leased by the household separately from cars that were purchased by the household. The 1992 survey data indicate that the median income (in 1992 dollars) for households that lease at least one car is $\$ 58,938$, while the median income for households that own at least one car (but do not lease) is $\$ 41,360$. These data are consistent with the idea that in 1992 many households with relatively high incomes chose to lease a car rather than purchase one. If leasing was not as popular an alternative for high-income households in 1983, this could explain the change in the sign of the coefficient on permanent income between 1983 and 1992. 
The Car Purchase Decision

1992 Survey of Consumer Finances

\begin{tabular}{|l|c|c|c|c|c|c|}
\hline & \multicolumn{3}{|c|}{ Full Sample } & \multicolumn{3}{c|}{ Excluding Self-Employed Households } \\
\cline { 2 - 7 } & 1 & 2 & 3 & 4 & 5 & 6 \\
\hline $\log \hat{Y}^{p}$ & -0.175 & 0.002 & 0.001 & -0.184 & 0.221 & 0.230 \\
& $\left(-2.976^{* * *}\right)$ & $(0.011)$ & $(0.004)$ & $\left(-2.295^{* *}\right)$ & $(0.709)$ & $(0.740)$ \\
\hline $\operatorname{Pr}(\hat{u})$ & -11.921 & -13.699 & -43.546 & -8.791 & -7.689 & -43.469 \\
& $\left(-3.214^{* *}\right)$ & $\left(-2.386^{* *}\right)$ & $\left(-2.396^{* *}\right)$ & $\left(-2.112^{* *}\right)$ & $(-1.189)$ & $\left(-1.996^{* *}\right)$ \\
\hline No. Children & & 0.075 & 0.075 & & 0.080 & 0.081 \\
& & $\left(2.085^{* *}\right)$ & $\left(2.073^{* *}\right)$ & & $\left(1.683^{*}\right)$ & $\left(1.695^{*}\right)$ \\
\hline No. Earners & & 0.196 & 0.195 & & 0.088 & 0.097 \\
& & $\left(2.182^{* *}\right)$ & $\left(2.168^{* *}\right)$ & & $(0.692)$ & $(0.761)$ \\
\hline Marital Status & & -0.080 & -0.068 & & 0.012 & 0.007 \\
& & $(-0.477)$ & $(-0.404)$ & & $(0.059)$ & $(0.034)$ \\
\hline Age & & 0.011 & 0.000 & & 0.006 & -0.008 \\
& & $(1.543)$ & $(0.026)$ & & $(0.557)$ & $(-0.587)$ \\
\hline Female Head & & -0.076 & -0.075 & & 0.105 & 0.102 \\
& $(-0.421)$ & $(-0.416)$ & & $(0.459)$ & $(0.446)$ \\
\hline Age $*$ Pr $(\hat{u})$ & & & 0.720 & & & 0.858 \\
& & & $\left(1.755^{*}\right)$ & & & $\left(1.741^{*}\right)$ \\
\hline OID Test & $97.74^{* * *}$ & 20.92 & 17.80 & $71.68^{* * *}$ & 16.67 & 13.60 \\
& & & & & & \\
\hline No. Observations & $9338 / 5$ & $9338 / 5$ & $9338 / 5$ & $5748 / 5$ & $5748 / 5$ & $5748 / 5$ \\
& & & & & & \\
\hline
\end{tabular}

* Significant at $10 \%$ or better. ** Significant at $5 \%$ or better. *** Significant at $1 \%$ or better.

Notes: The dependent variable equals one if a car was purchased within the last year; zero otherwise. $\operatorname{Pr}(\hat{u})$ is the probability of unemployment and $\hat{Y}^{p}$ is permanent income. t statistics are listed in parentheses below coefficient estimates. The following variables were included as independent variables but are not reported: education dimmy variables; occupation dummy variables; a standard likelihood ratio (LR) test.

Table 6: Estimation of the Car Purchase Decision

In summary, the results of this section suggest that unemployment risk is also a factor affecting households' car purchase decisions in the 1990s. As with the home purchase decision examined above, the results for the 1983 wave of the SCF look different from those for the 1992 wave of the SCF; but again, this may be related to the heightened responses of consumers to changes in uncertainty brought about by the financial deregulation, and the trend of increased household debt to income ratios between 1983 and 1992 .

\subsubsection{Liquid Assets After a Home Purchase}

As a final test of the strength of the precautionary saving motive, I examine more closely the state of individual households' balance sheets after a home purchase. Households who have just bought a home typically have low levels of liquid assets because of the large outlays associated with the purchase (down payments, closing costs, etc.). If the model's prediction is correct, then recent homebuyers who 
Liquid Assets After A Home Purchase

1983 Survey of Consumer Finances

\begin{tabular}{|l|c|c|c|c|c|c|}
\hline & \multicolumn{3}{|c|}{ Full Sample } & \multicolumn{3}{c|}{ Excluding Self-Employed Households } \\
\cline { 2 - 7 } & 1 & 2 & 3 & 4 & 5 & 6 \\
\hline $\log \hat{Y}^{p}$ & 1.867 & 1.478 & 1.409 & 1.832 & 1.483 & 1.405 \\
& $\left(4.039^{* * *}\right)$ & $\left(2.684^{* * *}\right)$ & $\left(2.527^{* * *}\right)$ & $\left(3.497^{* * *}\right)$ & $\left(2.459^{* *}\right)$ & $\left(2.321^{* *}\right)$ \\
\hline $\operatorname{Pr}(\hat{u})$ & -2.371 & 8.377 & 16.404 & 0.270 & 9.976 & 18.982 \\
& $(-0.219)$ & $(0.662)$ & $(1.239)$ & $(0.024)$ & $(0.769)$ & $(1.404)$ \\
\hline Age & & 0.000 & -0.000 & & -0.006 & -0.008 \\
& & $(0.018)$ & $(-0.007)$ & & $(-0.271)$ & $(-0.398)$ \\
\hline White & & & 1.123 & & & 1.311 \\
& & & $\left(1.931^{*}\right)$ & & & $\left(2.106^{* *}\right)$ \\
\hline No. Children & & & 0.083 & & & 0.112 \\
& & & $(0.563)$ & & & $(0.690)$ \\
\hline OID Test & 48.99 & 44.20 & 39.66 & 48.66 & 43.59 & 39.28 \\
& & & & & & 108 \\
\hline No. Observations & 126 & 126 & 126 & 108 & & 108 \\
& & & & & & \\
\hline
\end{tabular}

* Significant at $10 \%$ or better. ** Significant at $5 \%$ or better. *** Significant at $1 \%$ or better.

Notes: The dependent variable is the log of liquid assets. $\operatorname{Pr}(\hat{u})$ is the probability of unemployment and $\hat{Y}^{p}$ is permanent income. The sample includes only those households that have purchased a home within the last two years. t statistics are independent variables but are not reported. The test of overidentifying restrictions is a standard Lagrange multiplier (LM) indepent.

Table 7: Estimation of Liquid Assets of Recent Home Buyers

face a higher probability of an unemployment spell will have waited longer to buy the home and therefore will have more liquid assets left over after the actual purchase. In other words, because unemployment fears cause consumers to postpone a home purchase until they can accumulate more precautionary savings, we should observe a positive relationship between unemployment risk and the stock of liquid assets held by recent homebuyers. To test this proposition, an equation relating the stock of liquid assets held by recent homebuyers to permanent income, unemployment risk, and other variables is estimated. The results for these regressions are listed in Tables 7 and 8 .

After controlling for permanent income and other demographic variables, high risk households should have more assets than similar recent homebuyers whose risk of unemployment is not as high. Because the sample of recent homebuyers is very small (126 households in the 1983 SCF and roughly 211 households in the $1992 \mathrm{SCF}$ ), the set of control variables included is very minimal. The first column of each panel shows the baseline equation when only permanent income and unemployment risk are included as regressors; the second and third columns add education, age, race, and the number of children to the regression. 
Liquid Assets After A Home Purchase 1992 Survey of Consumer Finances

\begin{tabular}{|l|c|c|c|c|c|c|}
\hline \multirow{2}{*}{} & \multicolumn{3}{|c|}{ Full Sample } & \multicolumn{2}{c|}{ Excluding Self-Employed Households } \\
\cline { 2 - 7 } & 1 & 2 & 3 & 4 & 5 & 6 \\
\hline $\log \hat{Y}^{p}$ & 1.969 & 1.449 & 1.405 & 2.378 & 1.699 & 1.764 \\
& $\left(8.264^{* * *}\right)$ & $\left(4.713^{* * *}\right)$ & $\left(4.214^{* * *}\right)$ & $\left(7.577^{* * *}\right)$ & $\left(3.786^{* * *}\right)$ & $\left(3.617^{* * *}\right)$ \\
\hline $\operatorname{Pr}(\hat{u})$ & 35.015 & 32.322 & 41.829 & 32.481 & 33.807 & 44.933 \\
& $\left(2.533^{* * *}\right)$ & $\left(2.098^{* *}\right)$ & $\left(2.740^{* * *}\right)$ & $\left(2.071^{* *}\right)$ & $\left(1.922^{*}\right)$ & $\left(2.484^{* *}\right)$ \\
\hline Age & & 0.049 & 0.042 & & 0.050 & 0.038 \\
& & $\left(3.466^{* * *}\right)$ & $\left(2.845^{* * *}\right)$ & & $\left(2.781^{* * *}\right)$ & $\left(2.031^{* *}\right)$ \\
\hline White & & & 1.046 & & & 0.700 \\
& & & $\left(2.440^{* *}\right)$ & & & $(1.426)$ \\
\hline No. Children & & & -0.269 & & & -0.242 \\
& & & $\left(-2.293^{* * *}\right)$ & & & $\left(-1.605^{*}\right)$ \\
\hline OID Test & 51.15 & 40.15 & 28.05 & 42.02 & 31.44 & 26.42 \\
& & & & & & $662 / 5$ \\
\hline No. Observations & $1059 / 5$ & $1059 / 5$ & $1059 / 5$ & $662 / 5$ & $662 / 5$ \\
& & & & & & \\
\hline
\end{tabular}

* Significant at $10 \%$ or better. ** Significant at $5 \%$ or better. *** Significant at $1 \%$ or better.

Notes: The dependent variable is the $\log$ of liquid assets. $\operatorname{Pr}(\hat{u})$ is the probability of unemployment and $\hat{Y}^{p}$ is permanent income. The sample includes only those households that have purchased a home within the last two years. $t$ statistics are independent variables but are not reported. The test of overidentifying restrictions is a standard Lagrange multiplier (LM) test.

Table 8: Estimation of Liquid Assets of Recent Home Buyers

As expected, permanent income is highly statistically significant and positively related to the level of liquid assets held by the household. The elasticities with respect to permanent income range in size from 1.4 to 1.9 in the 1983 sample, and from 1.4 to 2.4 in the 1992 sample. While insignificant in the 1983 regressions, unemployment risk enters all of the 1992 equations with at least 90 percent confidence. The positive sign correctly predicts that households with a higher probability of unemployment tend to have more liquid assets remaining after a home purchase. In most cases, the other control variables are also statistically significant. Although the test of overidentification weakly rejects the baseline model for the 1992 sample (90 percent confidence), it fails to reject the model when additional variables are added to the regression.

\section{Conclusion}

The results in this paper demonstrate that individual household data on the timing of durable goods purchases are consistent with a theoretical model of consumption of durable and nondurable goods in which both labor income risk and household debt play a major role. A central implication of the 
model is that consumers respond to increases in unemployment risk by postponing purchases of the durable good in order to bolster their precautionary buffer-stock of liquid assets. Hence, households who face a higher probability of unemployment should be less likely to have recently purchased a durable good than households facing ordinary or low unemployment risks. This prediction is tested by estimating a probit model of the household's decision to purchase a durable good.

The results for the 1992 sample show that unemployment risk directly affects the timing of both home and car purchase decisions, even after controlling for several basic demographic variables. Although the results for the 1983 wave of the SCF do not indicate a statistically significant relationship between unemployment risk and home purchase decisions, the coefficients do have the expected signs. Another finding consistent with the theoretical model is that the coefficient for a variable capturing the interaction between age and unemployment risk has a positive sign, implying that the spending decisions of older consumers are less sensitive to unemployment risk. Finally, an examination of the balance sheets of consumers who have recently purchased a home reveals a positive and significant relationship between liquid assets and unemployment risk, suggesting the model is correct in predicting that consumers with greater income uncertainty will have more assets left over after a home purchase than consumers facing ordinary or low unemployment risks.

By incorporating labor income uncertainty and precautionary saving motives into the durable goods purchase problem, this paper provides a potential explanation for variations in consumer spending on durable goods over the business cycle. This is especially important because most of the variation in consumption over the business cycle reflects fluctuations in durable goods spending. Yet previous empirical work on durable goods using household level data has largely ignored the effects of labor income uncertainty. In addition, the results in this paper are important from a macroeconomic perspective because they provide evidence that precautionary saving models are based on valid assumptions about the microeconomic behavior of individual households.

The implications of the theoretical model presented here generate several potential topics for future research. For example, an important characteristic of the model is that the width of the (S,s) bands, or the 'inaction range,' will be wider for households who face greater unemployment risk. Increases in unemployment risk cause the $(\mathrm{S}, \mathrm{s})$ trigger to shift downward, implying that a consumer with a given house value will require a larger stock of precautionary liquid assets before he or she will be willing to 
buy a house. Therefore, an interesting topic for further work would be to estimate this "inaction range" to determine whether, as predicted by the theoretical model, unemployment risk is positively related to the width of the $(\mathrm{S}, \mathrm{s})$ band for home purchases. The results could be compared to those based on standard $(\mathrm{S}, \mathrm{s})$ models of durable goods, which until now have ignored labor income uncertainty in explaining fluctuations in durable goods purchases. One notable exception is Eberly (1994), who estimated the size of the "inaction range" for purchases of cars and found that it is positively related to income variability; however, the theoretical justification for this result is quite different from the one presented here. In Eberly (1994), an increase in uncertainty leads to less frequent adjustment of the stock of durables because it increases the present discounted value of adjustment costs the consumer would have to pay. Hence, the importance of uncertainty does not arise from precautionary motives as it does in the model presented here. 


\section{References}

Bar-Ilan, A., and A. S. Blinder (1992): "Consumer Durables: Evidence on the Optimality of Usually Doing Nothing," Journal of Money, Credit, and Banking, 24(2), 258-272.

Bertola, G., and R. J. Caballero (1990): "Kinked Adjustment Costs and Aggregate Dynamics," in NBER Macroeconomics Annual, ed. by O. J. Blanchard, and S. Fischer, pp. 237-288. MIT Press, Cambridge, MA.

Blanchard, O. J. (1993): "What Caused the Last Recession? Consumption and the Recession of 1990-1991," American Economic Review, 83(2), 270-274.

Caballero, R. J. (1990): "Consumption Puzzles and Precautionary Savings," Journal of Monetary Economics, 25, 113-136.

(1991): "Earnings Uncertainty and Aggregate Wealth Accumulation," American Economic Review, 81, 859-871.

(1993): "Durable Goods: An Explanation for Their Slow Adjustment," Journal of Political Economy, 101(2), 351-384.

Campbell, J. Y., and A. S. Deaton (1989): "Why Is Consumption So Smooth?," Review of Economic Studies, 56, 357-74.

Carroll, C. D. (1992): "The Buffer-Stock Theory of Saving: Some Macroeconomic Evidence," Brookings Papers on Economic Activity, 1992(2), 61-156.

_ (1997): "Buffer-Stock Saving and the Life Cycle/Permanent Income Hypothesis," Quarterly Journal of Economics, CXII(1), 1-56.

Carroll, C. D., and W. E. Dunn (1997a): "Data Sources and Solution Methods for Empirical and Theoretical Results in 'Unemployment Expectations, Jumping (S,s) Triggers, and Household Balance Sheets'," http://www.econ.jhu.edu/ccarroll.

(1997b): "Unemployment Expectations, Jumping (S,s) Triggers, and Household Balance

Sheets," in NBER Macroeconomics Annual, ed. by B. S. Bernanke, and J. Rotemberg. MIT Press, Cambridge, MA. 
Carroll, C. D., K. E. Dynan, and S. S. Krane (1997): "Unemployment Risk and Precautionary Wealth: Evidence from Households' Balance Sheets," Manuscript, Johns Hopkins University.

Deaton, A. S. (1991): "Saving and Liquidity Constraints," Econometrica, 59, 1221-1248.

— (1992): Understanding Consumption. Oxford University Press, New York.

Eberly, J. C. (1994): “Adjustment of Consumers' Durable Stocks: Evidence from Automobile Purchases," Journal of Political Economy, 102(3), 403-436.

_ (1997): "Flexible (S,s) Bands, Uncertainty, and Aggregate Consumer Durables Purchases," Working Paper, University of Pennsylvania.

Faber, J. (1982): "Life Tables for the United States: 1900-2050," U.S. Department of Health and Human Services, Social Security Administration, Actuarial Study No. 87.

Flavin, M. A. (1981): "The Adjustment of Consumption to Changing Expectations About Future Income," Journal of Political Economy, 8, 974-1009.

Fratantoni, M. C. (1996): "Housing Wealth, Precautionary Saving and the Equity Premium," Manuscript, The Johns Hopkins University.

Grossman, S. J., and G. S. Laroque (1990): "Asset Pricing and Optimal Portfolio Choice in the Presence of Illiquid Durable Consumption Goods," Econometrica, 58(1), 25-51.

Hall, R. E. (1993): "Macro Theory and the Recession of 1990-1991," American Economic Review, $83(2), 275-279$.

Hubbard, R. G., J. S. Skinner, and S. P. Zeldes (1994): "The Importance of Precautionary Motives for Explaining Individual and Aggregate Saving," in The Carnegie-Rochester Conference Series on Public Policy, ed. by A. H. Meltzer, and C. I. Plosser, vol. 40, pp. 59-126.

(1995): "Precautionary Saving and Social Insurance," Journal of Political Economy, 103, $330-399$.

Sichel, D. S. (1993): "Business Cycle Asymmetries: A Deeper Look," Economic Inquiry, pp. 224236. 
_ (1994): "Inventories and the Three Stages of the Business Cycle," Journal of Business and Economic Statistics, 12, 269-277.

Zeldes, S. P. (1989): “Optimal Consumption with Stochastic Income: Deviations from Certainty Equivalence," Quarterly Journal of Economics, 104, 275-298. 